
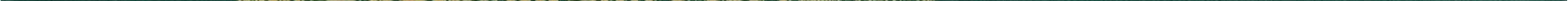


\section{KUML 1991-92}

Årbog for Jysk Arkæologisk Selskab

With summaries in English 
Redaktion: Hans Jørgen Madsen og Birgit M. Rasmussen

Redaktionsudvalg:

Jens Henrik Bech, Thisted

Steen Hvass, Vejle

Stig Jensen, Ribe

Erik Johansen, Aalborg

Steen W. Andersen, Haderslev

Lay-out og omslag: Jorgen Mührmann-Lund

Grafisk tilrettelagggelse: Elsebet Morville

Tryk: Special-Trykkeriet Viborg a-s

Skrift: Bembo 11/12

Papir: Stora G-Print $120 \mathrm{~g}$

Copyright 1994 by Jysk Arkaologisk Selskab

ISBN 87-7288-575-0

ISSN 0454-6245 


\section{Indhold/Contents}

Flemming Kaul: Ritualer med menneskeknogler i yngre stenalder ........................... 7

Neolithic Rituals involving Human Bones ................................................ 50

Anne Birgitte Sorensen: Enkeltgrave fra Rødding-egnen ...................................... 53

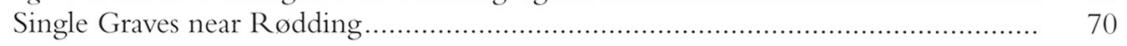

Bent Aaby, David Robinson og Anne Bloch Jørgensen: En gård fra førromersk jernalder og det omgivende landskab.....

A Pre-Roman Iron Age Settlement at Børglumvej, Århus:

Archaeology and Environment.

Orla Madsen: Søndervang ved Bjerre

En østjysk gravplads fra yngre germansk jernalder og vikingetid

Søndervang at Bjerre. A Cemetery from the Late Germanic and Viking periods in eastern Jutland ....

Bjarne Lonborg: Fremstillingen af vikingetidens skålformede fibler

The method of production of Viking Age tortoise brooches

Annette Hoff og Jens Jeppesen: Todderup

En udgravet torpbebyggelse og torperne historisk belyst

Todderup. The Excavation of a "torp" and the place of torps in history

Jysk Arkæologisk Selskab 1991 og 1992 


\title{
Enkeltgrave fra Rødding-egnen
}

\author{
Af Anne Birgitte Sørensen
}

På et højdedrag nord for Rødding i Sønderjylland har der engang nær Bakkegården ligget en flot række af oldtidshøje (fig. 1). Idag er disse høje generelt meget nedpløjede bortset fra den ene, der er fredet. I forbindelse med Rødding kommunes udstykning af området undersøgte Haderslev Museum i foråret og sommeren 1985 to af højrækkens overpløjede gravhøje (1). I Nationalmuseets sognebeskrivelse for Rødding sogn har de to høje sb. nr. 3 og 6.

\section{Bakkegården - sb. nr. 6}

Den vestligste gravhøj-sb. nr. 6 - så ud til at være den bedst bevarede, og inden muldafrømningen fremstod den som en svag runding på højdedraget. Undersøgelsen viste imidlertid, at højen var anlagt på en naturlig bakke i terrænet, så der var stort set intet tilbage af selve højfylden. Ikke desto mindre fremkom umiddelbart under pløjelaget to grave - nr. 10 og 11 - anlagt ved siden af hinanden i højens midte (fig. 2).

Gravene viste sig som to omtrent øst-vest-orienterede, tilnærmelsesvis rektangulære nedgravninger - 230-250 cm lange og 120-150 cm brede, med nærmest flad bund. I begge tilfælde dannede en brolægning af små, rundede marksten leje for en plankekiste. Brolægningerne var rektangulære og målte 60-70 x 160-175 cm. Ud over disse fællestræk udviste gravene også visse forskelle.

Grav 10 (fig. 3) havde således en række store sten og stenspor langs nedgravningens syd- og vestkant samt et enkelt stenspor ved nordsiden, og graven var kun 30-40 cm dyb. På bundens stenlægning fandtes i sydvesthjørnet en stridsøkse og ved nordkanten en flintkniv lavet på et afslag af en sleben økse (fig. 4). Oldsagerne var omgivet af et tyndt, brunt, fedtet lag, som også fandtes på stenlægningen. Dette lag var rester af kisten. Af skelettet var der ingen spor.

Grav 11 (fig. 5) var noget dybere nedgravet $-56 \mathrm{~cm}-$ og havde kun enkelte sten og stenspor langs siderne. Nordsiden var dog forstyrret af en moderne nedgravning. I selve graven, især i østenden, var der spor af dyreaktivitet. Ellers syntes graven at være velbevaret. Langs sydkanten fandtes en tynd bræmme af trækul, der kunne følges fra nedgravningens øverste kant og helt ned til gravbundens stenlægning. Det var rester af plankekistens ene langside, der målte op til $182 \mathrm{~cm}$ i længden. Planken hældede skråt udad og må være væltet ud i forhold til sin oprindelige placering. Den har været hærdet med ild måske for at blive mere holdbar. Nede på stenlægningen fremkom også rester af kisten - et tyndt, brunt, fedtet lag - samt to ovale ravskiver med gennemboring i midten (fig. 6). De lå i sydvest- og sydøsthjørnet på kistesporene. Det kunne ikke afgøres, om de også var dækket af kistespor, og om kisten således har haft låg. Der fandtes ingen skeletspor. 


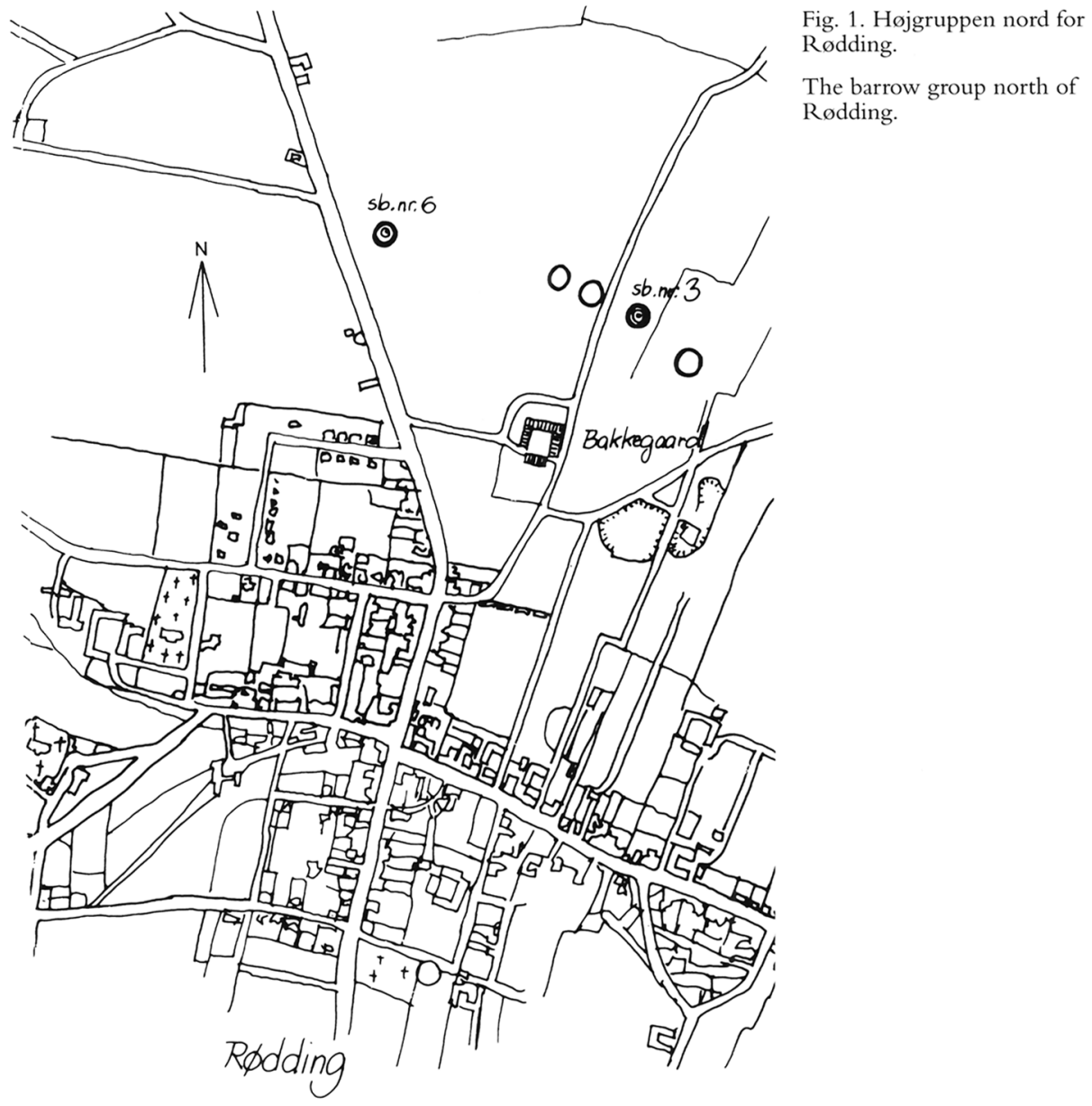

De to grave lå helt tæet sammen med samme orientering og indretning, som om de var anlagt samtidigt. Den ene grav - den med stridsøksen - er tydeligvis en mandsgrav. Den anden grav kan formentlig også anses for at være en mandsgrav, idet ravskiver almindeligvis regnes for mandsudstyr. Det var ellers en fristende tanke, at der kunne være tale om en kvindegrav, så det var mand og kone, der var gravlagt sammen i højen. Spørgsmålet er, hvor entydigt ravskiverne egentlig knytter sig til mandsudstyret, idet Glob nævner 17 tilfælde, hvor de er fundet sammen med talrige andre ravsmykker (2). Ravskivernes placering i de to sydlige hjørner af graven er ikke typisk, idet de almindeligvis findes midt $\mathrm{i}$ graven ved bæltestedet.

Stridsøksen (fig. 4), Globs type D-5, (3) kan dateres til den yngre del af enkeltgravskulturens ældste periode - undergravstid.

I højens vestlige udkant fandtes iøvrigt en fladbundet grube med bopladskeramik fra yngre undergravstid (4).

På bunden af den tidligere omtalte moderne nedgravning lå en samling hovedstore og to meget store sten. Måske er det resterne af den enkeltgrav, som 


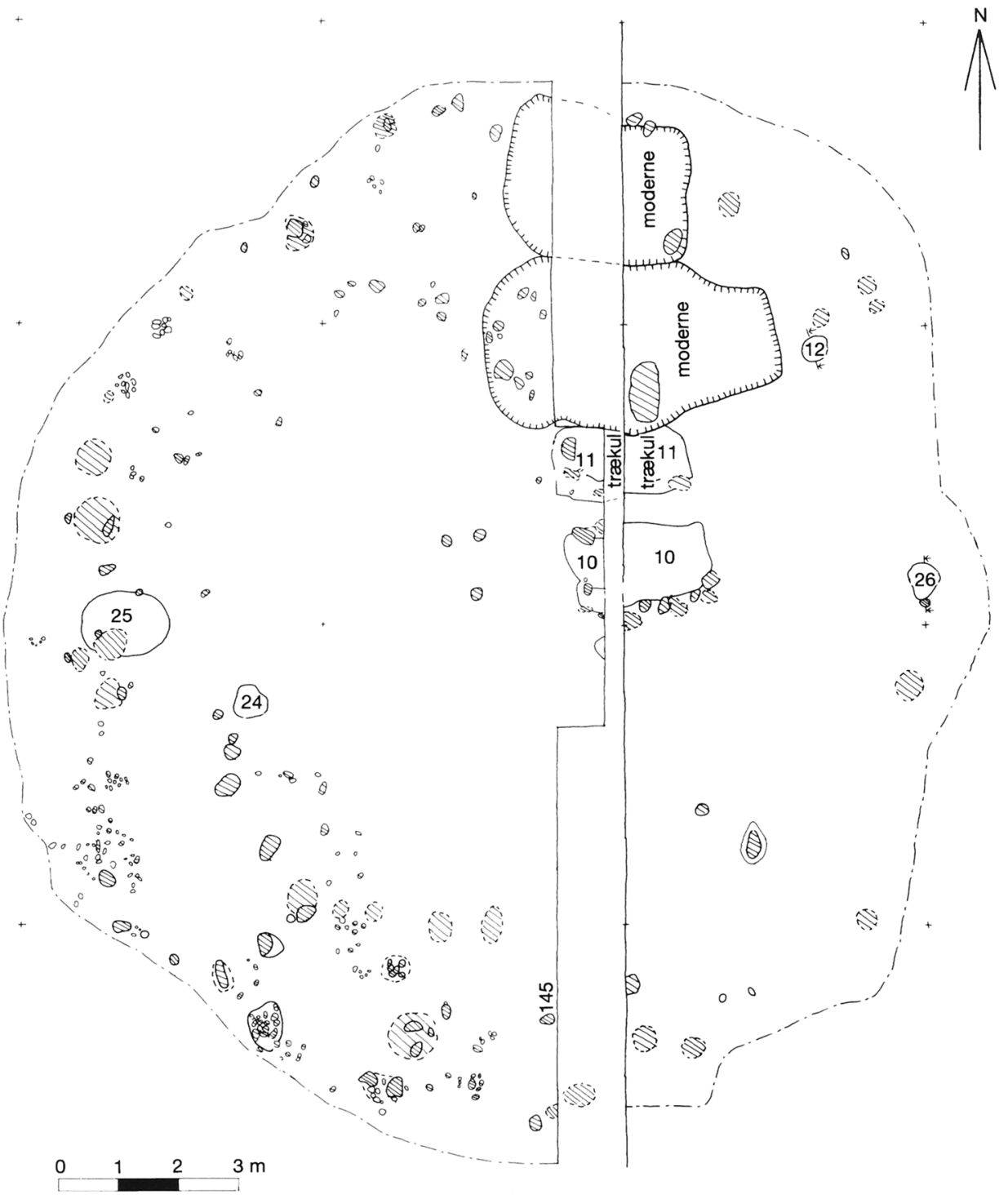

Fig. 2. Oversigtstegning af den udgravede høj - sb. 6.

General plan of the excavated barrow, sb. 6 .

skulle være udgravet i højen omkring århundredskiftet; men herom kan man kun gætte.

En egentlig randstenskæde lod sig ikke påvise, men enkelte sten og stenspor angiver højens omtrentlige diameter til ca. $16 \mathrm{~m}$.

Bakkegården - sb. nr. 3

3-400 m længere mod øst lå den anden gravhøj (5). Højen så umiddelbart ud til at være helt nedpløjet. Faktisk røbedes den kun af en næsten usynlig aflang 
Flintkniv nr. 1764 × 14

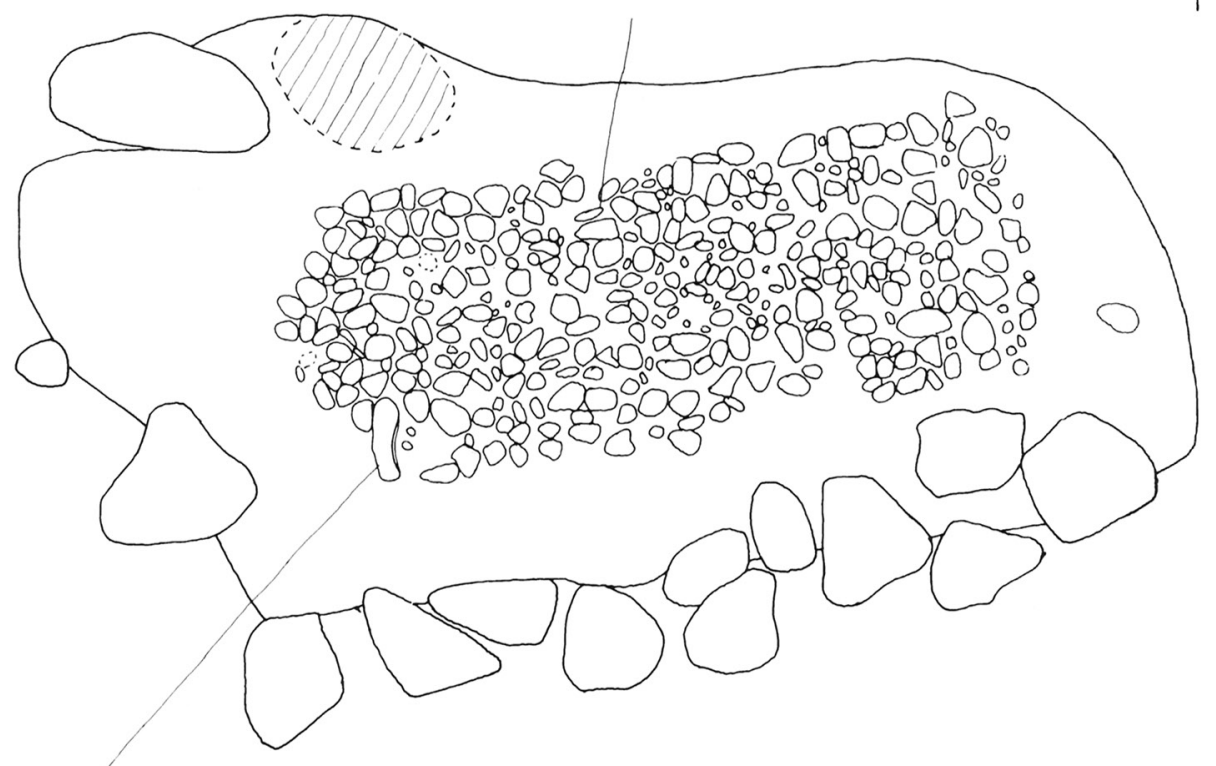

Stridsøkse nr. $1764 \times 18$
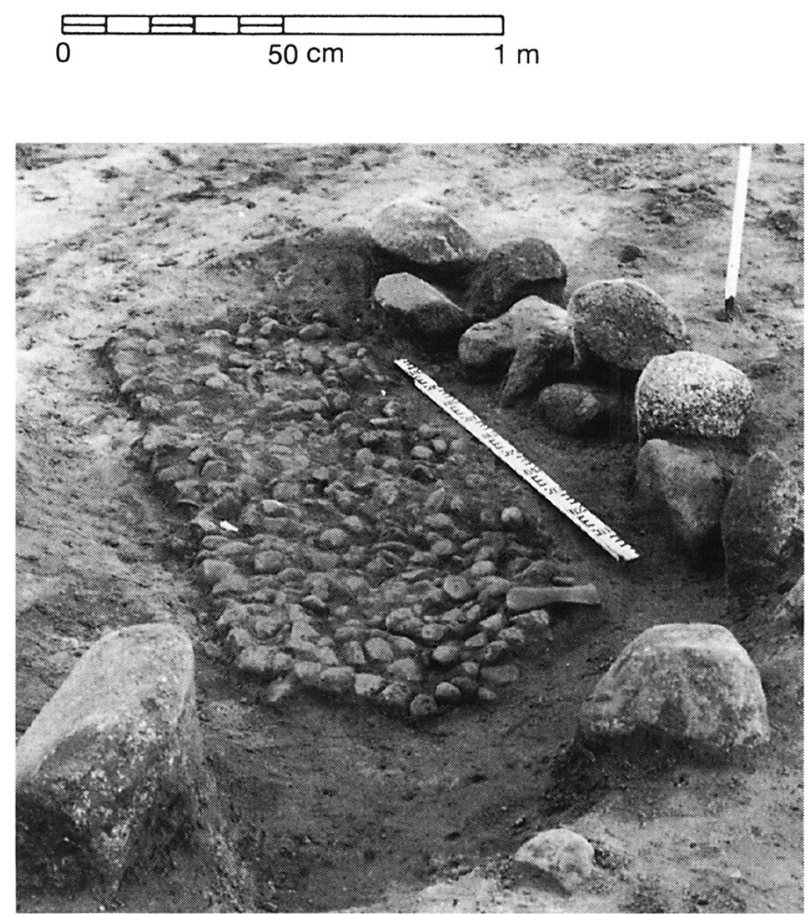

Fig. 3. Grav 10 med gravgodset frilagt.

Grave 10 with grave goods exposed. 

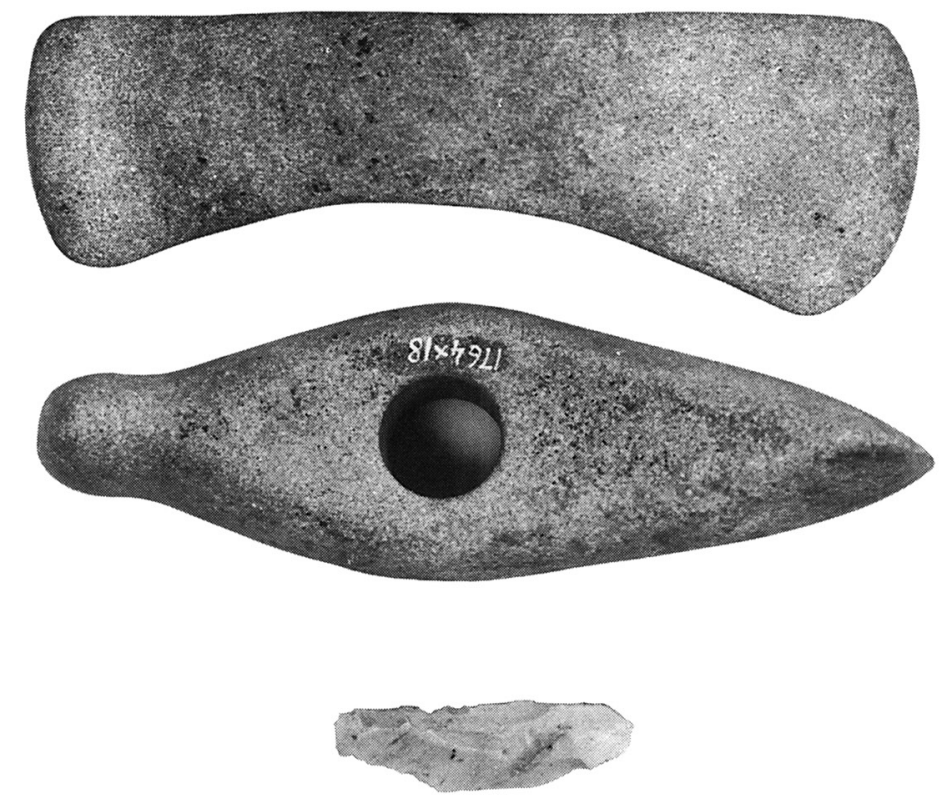

Fig. 4. Gravgodset fra grav 10: En stridsøkse - længde 17,5 cm - og en lille flintkniv lavet på et afslag af en sleben økse - længde $6,3 \mathrm{~cm} .1: 2$.

Objects from grave 10: battleaxe, length $17.5 \mathrm{~cm}$, and a small flint knife made on a flake from a polished axe, length $6.3 \mathrm{~cm} .1: 2$.

højning i terrænet, enkelte spredte sten og en udtørret plet i mulden. I betragtning af højens dårlige tilstand var det en glædelig overraskelse overhovedet at finde begravelser $\mathrm{i}$ den, men at fundene skulle blive så mange og så gode havde vi ikke forventet: Hele tre begravelser fra enkeltgravskulturen, otte-ni urnebegravelser - hovedsagelig fra førromersk og ældre romersk jernalder samt tre jordfæstegrave fra yngre romersk jernalder (fig. 7). Her skal dog kun stenaldergravene - grav 1, 2 og 4 - omtales. Det øvrige materiale er delvist publiceret andetsteds.

Grav 1 (fig. 8) - en ringgrøftgrav - var den sydligste af de tre grave. Selve gravens omrids var meget vanskeligt at skelne i fladen på grund af et virvar af udpløjede og væltede sten. Den viste sig at være en nærmest rektangulær sydvestnordøst orienteret nedgravning, der var op til $185 \mathrm{~cm}$ bred og $270 \mathrm{~cm}$ lang.

Nedgravningen var $90 \mathrm{~cm}$ dyb med stejle sider og nærmest flad bund. Rundt langs kanterne og helt ned til bunden sås en ramme af opstablede større og mindre sten. På bunden fandtes en nærmest rektangulær 130x80 cm stor brolægning af små, runde, smuldrende sten (7). For hver ende afsluttedes denne brolægning af to-fire flade sten, der var delvist dækket af den omgivende stenramme (fig 9). Bundbrolægningen har således oprindelig dækket et areal på 205x80 $\mathrm{cm}$. 

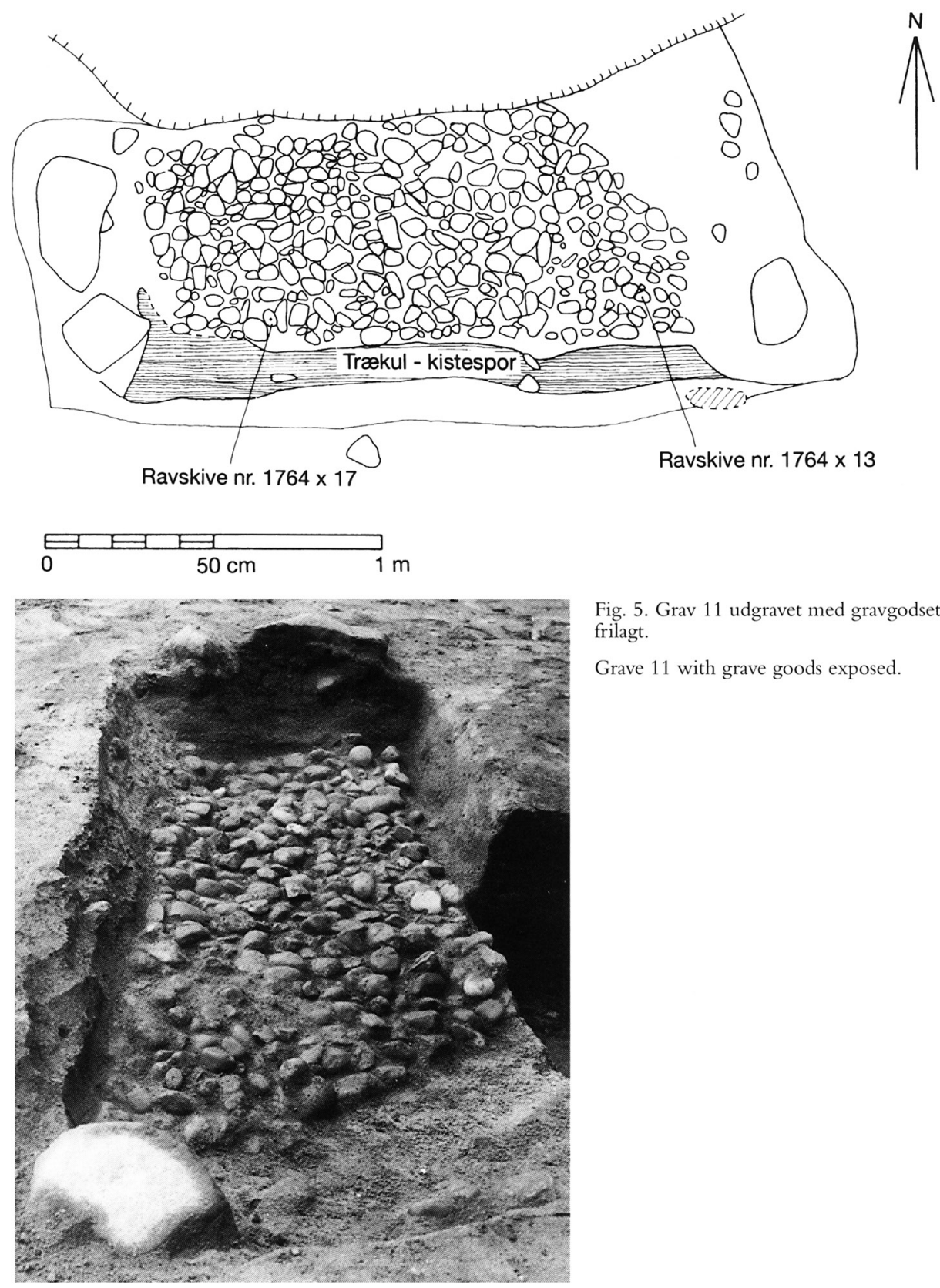

Fig. 5. Grav 11 udgravet med gravgodset frilagt.

Grave 11 with grave goods exposed.

På bundbrolægningen fandtes et meget tyndt, brunt, fedtet lag. Dette må sammen med lag d og $\mathrm{m}$ være resterne af kisten (fig. 10).

Lag $\mathrm{m}$, der fremstod som en lomme med sortbrunt, muldet sand og trækul ved den nordlige langside mellem bundbrolægningens kant og stenrammens nederste skifte, må være rester af den nederste del af en kantstillet planke, som har stået fastklemt her. Noget tilsvarende kunne ikke iagttages ved den anden lang- 

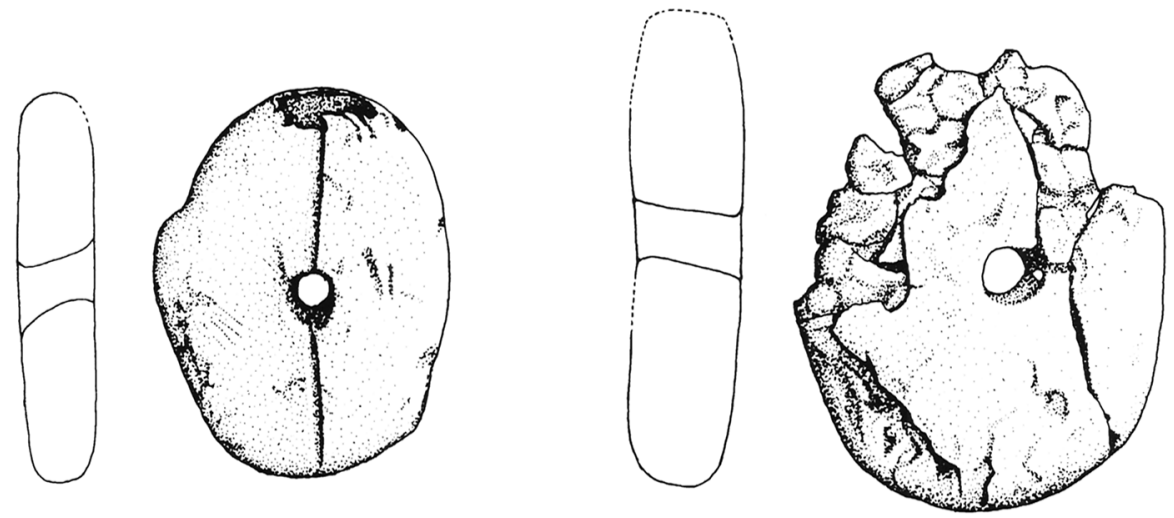

Fig. 6. Gravgodset fra grav 11: To ovale ravskiver med gennemboring i midten henholdsvis 3,0x3,85 og $3,8 \times 4,7 \mathrm{~cm}$ store. Den ene er ornamenteret med en indridset linje.

Grave goods from grave 11: Two oval amber discs with central perforation, measuring respectively $3.0 \times 3.85$ and $3.8 \times 4.7 \mathrm{~cm}$. One is decorated with an incised line.
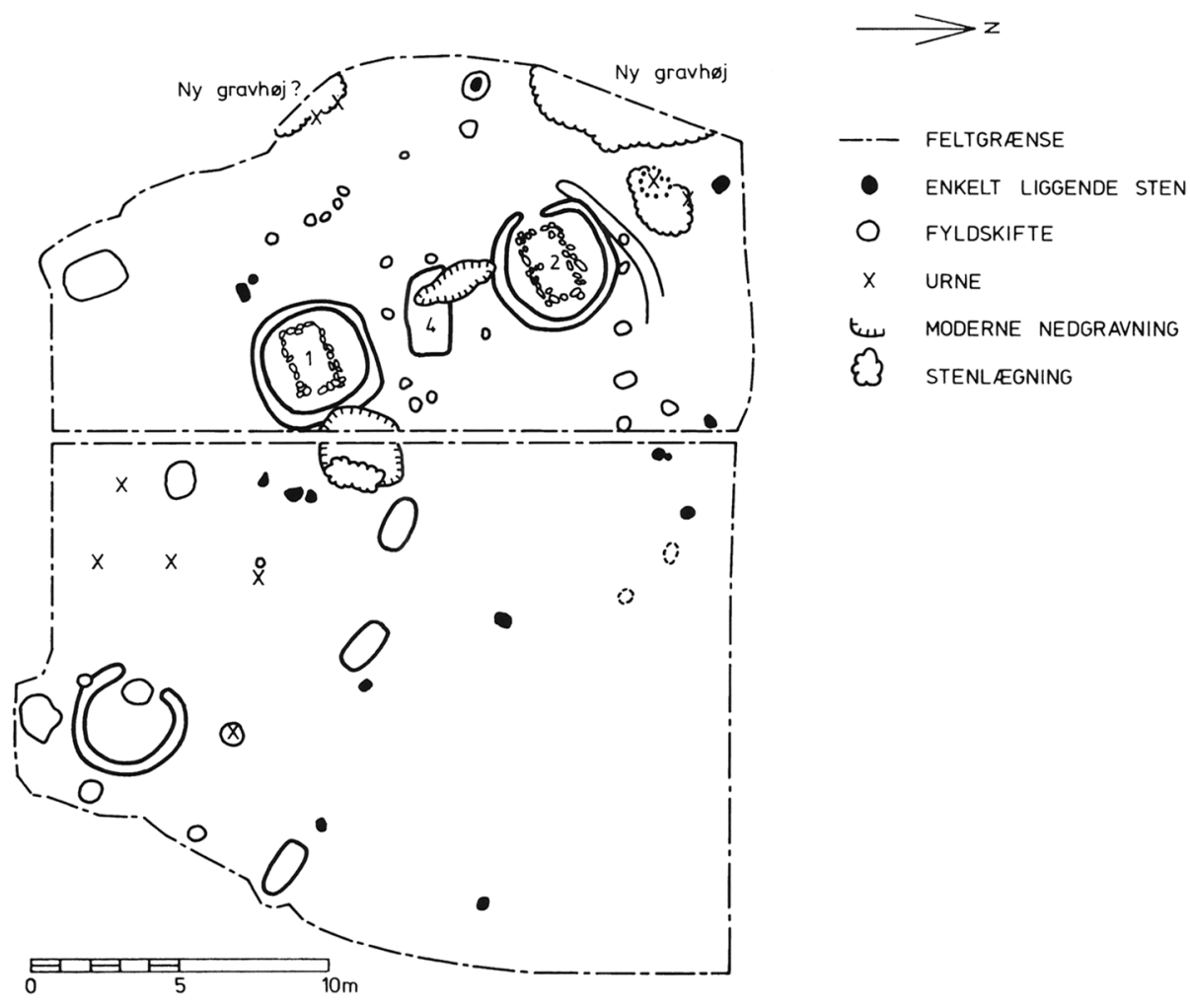

Fig. 7. Oversigtstegning af de udgravede anlæg i højen sb. 3.

General plan of the excavated features in the barrow, sb. 3 . 


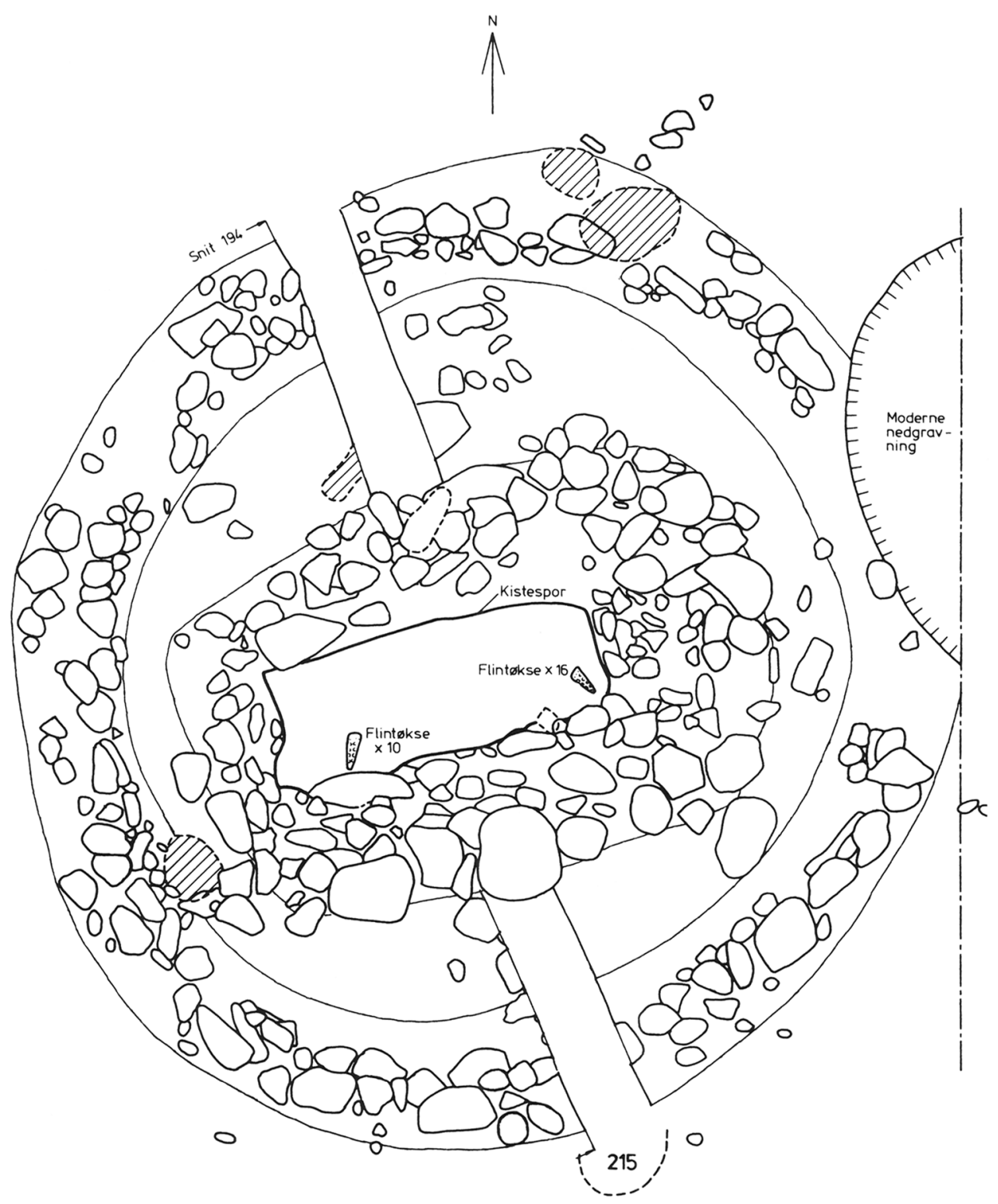

Fig. 8. Grav 1 med kistespor og gravgodset frilagt.

Grave 1 with grave goods and traces of coffin exposed.

side. Lag d er formentlig rester af låget. Kistesporene målte op til 160 x $60 \mathrm{~cm}$.

På bundbrolægningen fandtes 2 flintøkser. Den ene - en tyknakket økse - lå i det sydvestlige hjørne ud for den dødes ansigt. Den anden, der var tyndbladet, lå i det sydøstlige hjørne (fig. 11). Begge havde kistespor over og under sig, og begge var anbragt med æggen pegende mod nord - ind mod den døde. Der fandtes kun ganske svage skeletspor . 
Fig. 9. Grav 1 set fra vest. Stenrammen er fjernet, og bundbrolegningen og de flade sten ved enderne er frilagt.

Grave 1 from the west. The stone framing has been removed and the floor cobbling and the flat stones at the ends are exposed.

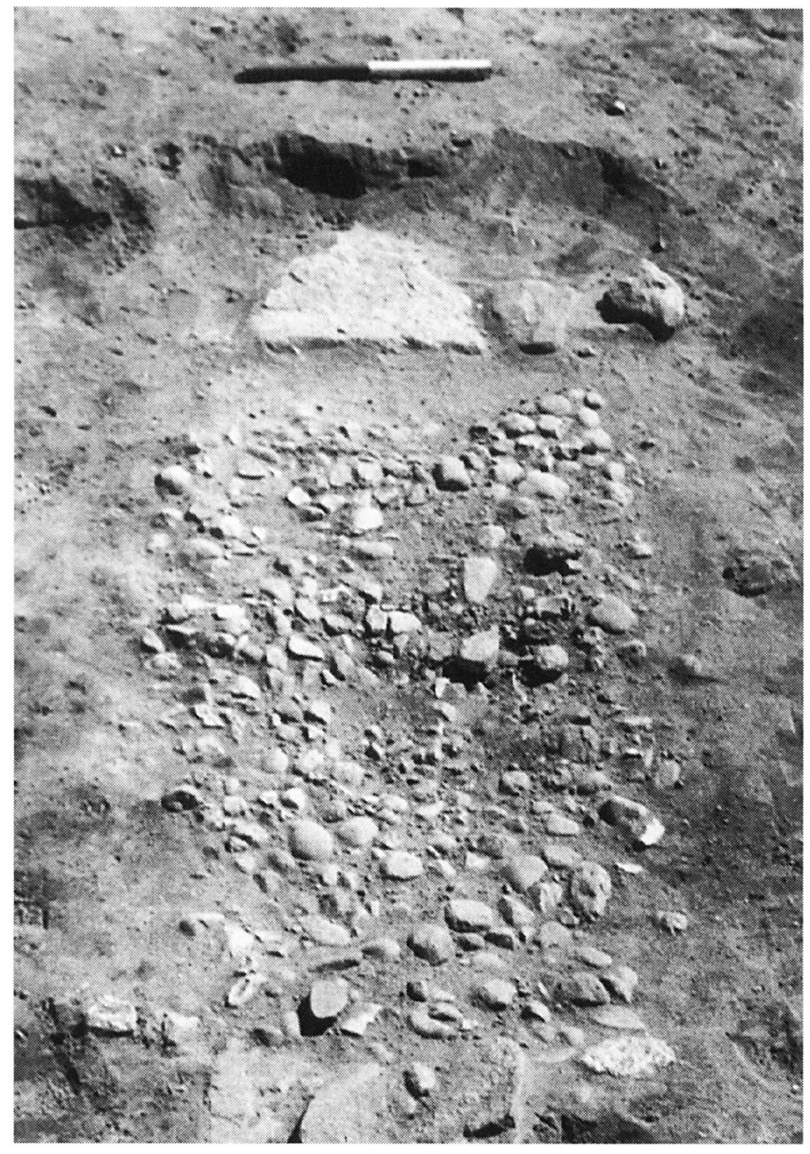

Ringgrøften omkring grav 1 viste sig i fladen som en diffus, lys ring af vekslende bredde omkring graven. Den målte op til $450 \mathrm{~cm}$ i diameter og var op til $66 \mathrm{~cm}$ dyb. I grøften var der anbragt en mængde større og mindre sten. Enkelte steder var disse sten tydeligt stablet i to rækker med plads til stolper mellem rækkerne; de fleste steder kunne der dog kun iagttages én stenrække, og på et stykke i grøftens østlige del manglede stenene helt på grund af en moderne forstyrrelse. I snittet viste stolpeaftryk (fig. 10, lag f og h), at stolperne har stået lodret. Det er uvist, hvor tæt stolperne har stået i grøften, men de er formentlig trukket op, før højen er blevet rejst. I området mellem graven og ringgrøften fandtes enkelte stolpehuller. Der er dog tilsyneladende intet system i deres placering.

Grav 2 (fig. 12) fremstod både i snit og i flade som en næsten fuldstændig kopi af grav 1. Der var dog enkelte forskelle. Således var grav 2 lidt bredere - op til $195 \mathrm{~cm}$ - men havde samme længde. Den var knap så dyb, kun $56 \mathrm{~cm}$. Stenbrolægningen på gravens bund var lidt større end i grav $1-85 \times 180 \mathrm{~cm}$; men var også her afsluttet af flade sten - ialt fire -, der skrånede ind mod bundbrolægningen og var delvis dækket af den omgivende stenramme. Bundbrolægningen har således ialt målt 220x85 cm. 


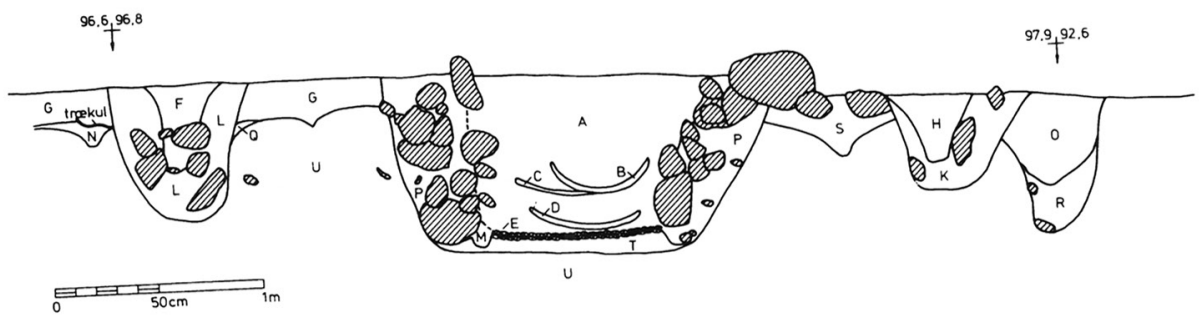

Fig. 10. Snit af grav 1 med ringgrøft. Lagbeskrivelse: a: Plettet gul/lysebrun, leret sand med småsten. b: Gråhvide sandstriber. c: Brun sandstribe. d: Mørkebrun, fedtet sandstribe - kistespor? e: stenlægning med kistespor ovenpå - brunt, fedtet lag. f: Hvidgråt sand med mørkere pletter, småsten og trækul. g: Spættet mellembrunt/lysebrunt sand med mørkere og lysere pletter, småsten og trækul. h: Plettet lysgult/lysbrunt/ gråt sand med småsten. k: Mellembrunt, muldet sand med trækul. l: som g, dog lidt mørkere. m: Sortbrunt, muldet sand med trækul. n: som g, dog lidt mørkere. o: som k. p: som k, dog lysere og med store sten. q: Linse med lysgråt sand i g. r: som k, dog mere grå og lysere - fyldskifte 215. s: Lysebrunt sand med trækul gammel overflade. t: leret, gult til gråt sand med trækulsnister og småsten. u: Gult, lerblandet sand med hvidt grus, vekslende med mørkegult til lysebrunt, groft, lerblandet sand med grus - undergrund.

Section through grave 1 with ring ditch. Description of layers: a: spotted, yellow/light-brown clayey sand with small stones. b: greyish white sand lenses. c: lens of brown sand. d: dark brown, sticky sand - remains of coffin? e: laid stones with traces of cist above - brown, sticky layer. f: whitish grey sand with darker patches, small stones, and charcoal. g: spotted medium-brown/light brown/grey sand with small stones. h: spotted light-yellow/light-brown/grey sand with small stones. k: medium brown, humic sand with charcoal. l: like g, but slightly darker. m: black-brown, humic sand with charcoal. n: like g, but slightly darker. o: like k. p: like $\mathrm{k}$, but paler and with large stones. q: lens of pale grey sand in g. r: like k, but greyer and paler - context 215. $\mathrm{s}$ : light brown sand with charcoal - old ground surface. t: clayey yellow to grey sand with small stones and specks of charcoal. u: yellow clayey sand with white gravel alternating with dark yellow, coarser sand.
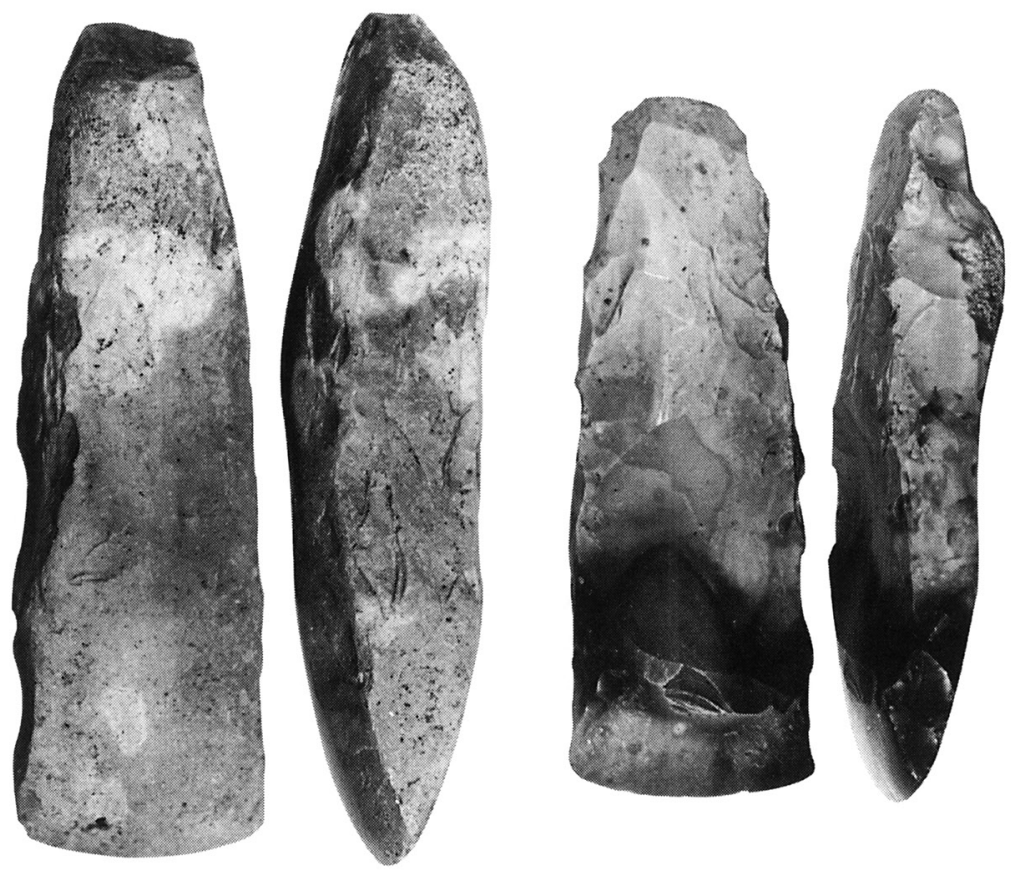

Fig. 11. Gravgodset fra grav 1: En tyknakket flintøkse - længde $16,8 \mathrm{~cm}$, og en tyndbladet flintøkse - 14,1 cm lang. 1:2

The gravegoods from grave 1: A thickbuttet flint axe, length $16.8 \mathrm{~cm}$, and a thin bladed flint axe, length $14,1 \mathrm{~cm} .1: 2$. 


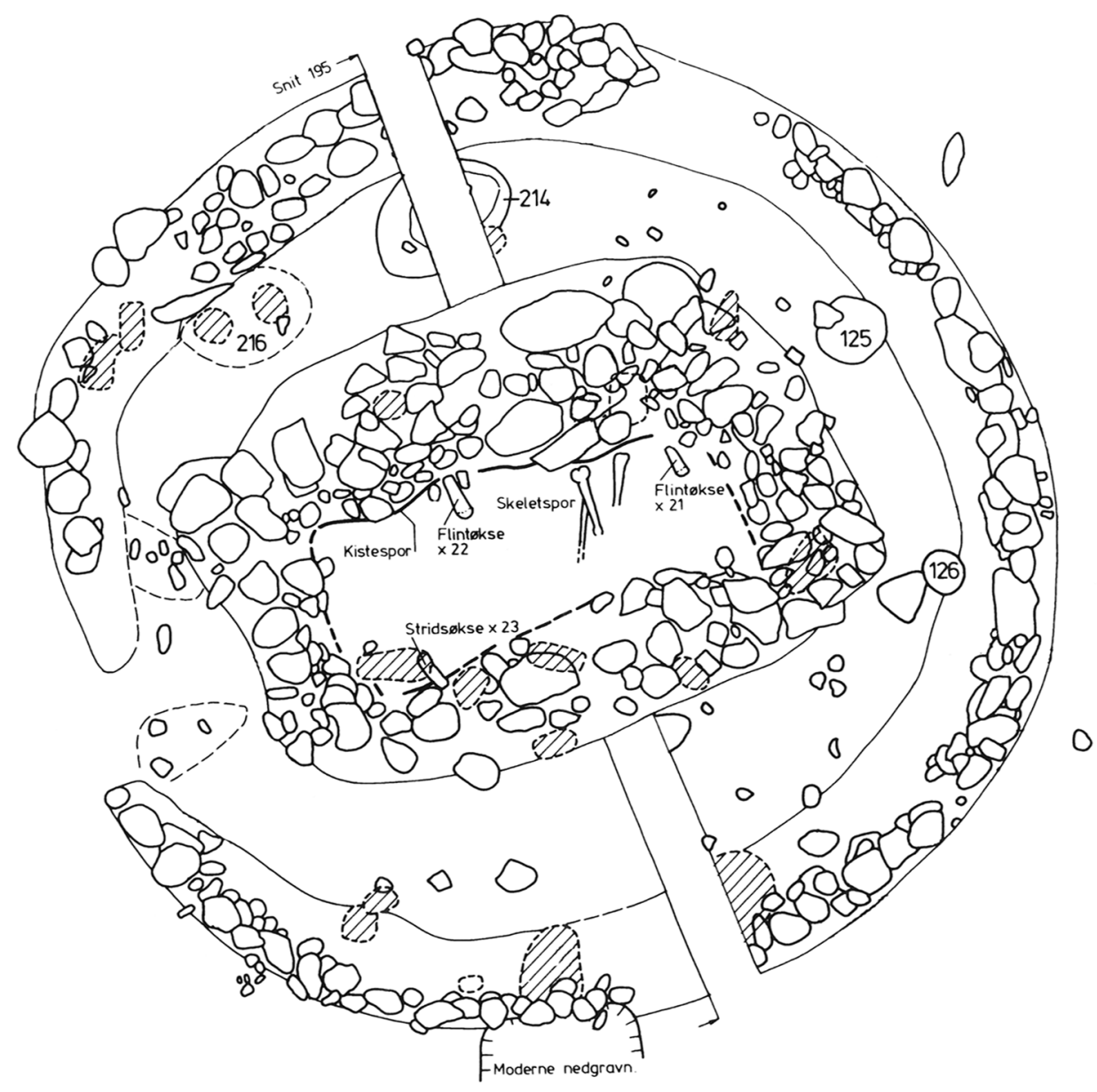

Fig. 12. Grav 2 med gravgods samt skelet- og kistespor frilagt.

Grave 2 with grave goods and traces of skeleton and coffin exposed.

Også her fandtes kistepor, og i snittet sås næsten endnu tydeligere end i grav 1 sporene af kantstillede planker fastklemt ved begge sider mellem bundbrolægningen og stenrammen (fig. 13, lag h og k). Ved langsiderne var kistens kanter brækket ind på grund af indvæltede sten fra stenrammen. Kisten har formentlig bestået af løse planker - én eller flere på stenlægningen som bund, kantstillede planker langs siderne og én eller flere lagt over som låg.

Ligeledes var der med hensyn til gravgodset en vis overensstemmelse mellem grav 1 og 2 (fig. 14), idet grav 2 ligeledes indeholdt to flintøkser - en tyknakket og en tyndbladet - men derudover også en stridsøkse af Globs type B-1 (8). Her var stridsøksen placeret i det sydvestlige hjørne ud for den dødes ansigt. Den tyknakkede økse lå omtrent midt for nordsiden, altså ved bæltestedet bag den dødes ryg, mens den tyndbladede økse fandtes i det nordøstlige hjørne ved fødderne (fig. 12). Alle økserne var anbragt med æggen pegende ind mod gravens midte og alle med kistespor over og under sig. 
I niveau med gravudstyret fandtes svage spor af skelettet, hvoraf bækkenparti, lårben og dele af skinneben kunne erkendes, hvilket viste, at den døde har ligget i sammenkrøbet sovestilling.

Gravgodsets placering i gravene viser tydeligt, at den vigtigste plads i mandsgraven er det sydvestlige hjørne ud for den dødes ansigt. Her anbringes øksen med den højeste statusværdi: stridsøksen, eller det næstbedste: den tyknakkede flintøkse.

Ringgrøften omkring graven lignede også meget grav 1's, men var knap så stor kun $420 \mathrm{~cm}$ i diameter og kun op til $40 \mathrm{~cm}$ dyb. Opbygningen med de mange sten var stort set den samme: Opstablede sten $\mathrm{i}$ to rækker i grøftens nordlige del. I resten af grøften var stenene omhyggeligt stablet lodret oven på hinanden i op til fem skifter i én række langs yderkanten.

Også her viste snittet, at grøftens stolper har stået lodret (fig. 13, lag d og i), og at de er blevet fjernet inden opførelsen af højen.

Opbygningen af de to ringgrøfter er således stort set ens, men på ét punkt er der en forskel: Ringgrøften ved grav 2 var forsynet med en $50 \mathrm{~cm}$ bred åbning mod vest, så der fremkom en slags tærskel eller indgang til gravanlægget. Her viste der sig omtrent i niveau med det øverste stenskifte i grøften to lave, ovale gruber mellem ringgrøftens ender og gravens vestende. Gruberne var forsynet med et antal mindre sten. Måske har de forbindelse med åbningen i ringgrøften, men det var ikke muligt at dokumentere deres samhørighed med anlægget tilfredsstillende.

Ved østenden af grav 2 fandtes inden for ringgrøften to stolpehuller, der kan have været med til at bære en form for overbygning til graven. Stolperne har skrånet mod øst, men både dybde og diameter var meget uensartet (9).

De to ringgrøftanlæg har efter al sandsynlighed haft hver sin høj over sig. Der

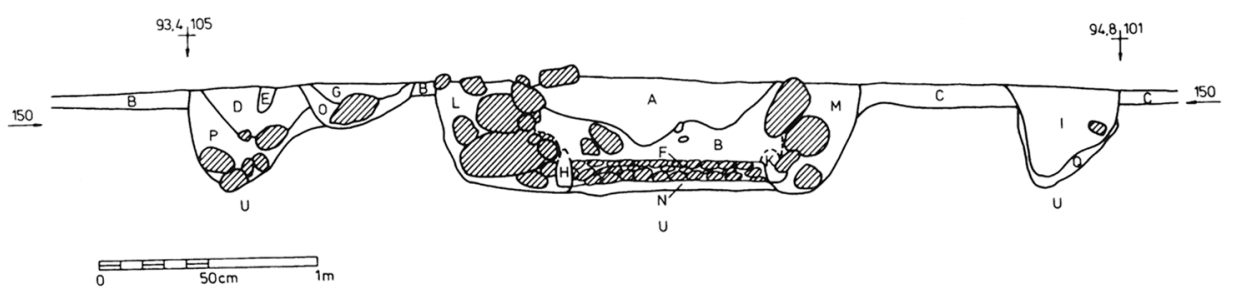

Fig. 13. Snit af grav 2 med ringgrøft. Lagbeskrivelse: a: Spættet gult/lysebrunt/mørkebrunt, muldet sand med småsten. b: Mellembrunt muldet sand med små og store sten og trækul. c: Spættet grăt/brunt/gult sand med småsten og trækul. d: Spættet gråhvidt/gult/lysebrunt/mørkebrunt sand med småsten og trækulsnister. e: Brunt, muldet sand - pælehul? f: Stenlægning med ildskørnede småsten blandet med gult og lysebrunt sand og trækulsnister. g: som d. h: Brunt, muldet sand med trækul - plankespor? i: som d. k: som h - plankespor (kiste). l: som b. m: som l. n: Gult og lysebrunt sand med trekulsnister. o: som b. p: som b. q: som c. u: Gult lerblandet sand med grus, vekslende med mørkgult, grovere og mere gruset sand.

Section through grave 2 with ring ditch. Description of the layers: a: spotted, yellow/light-brown/darkbrown humic sand with small stones. b: medium brown humic sand with small and large stones and charcoal. c: spotted grey/brown/yellow sand with small stones and charcoal. d: spotted greyish white/yellow, lightbrown/dark-brown sand with small stones, and charcoal. e: brown, humic sand - posthole? f: laid stones with calcinated small stones mixed with yellow and light-brown sand, and charcoal. g: like d. h: brown, humic sand with charcoal - traces of planks? i: like d. k: like h - traces of planks (coffin). l: like b. m: like l. n: yellow and light-brown sand with charcoal. o: like b. p: like b. q: like c. u: yellow clayey sand with gravel alternating with dark yellow, coarser sand. 
har formentlig kun været tale om småhøje, der kun lige har dækket ringgrøfterne (10).

Efter anlæggene at dømme er de to grave anlagt nogenlunde samtidigt. Både den ensartede opbygning og selve anlægstypen, der tidsmæssigt er begrænset til tidlig enkeltgravskultur, tyder i den retning. Ud fra stridsøksen, Globs type B1-2, (11) kan de dateres til den ældre del af enkeltgravskulturens ældste periode - undergravstid.
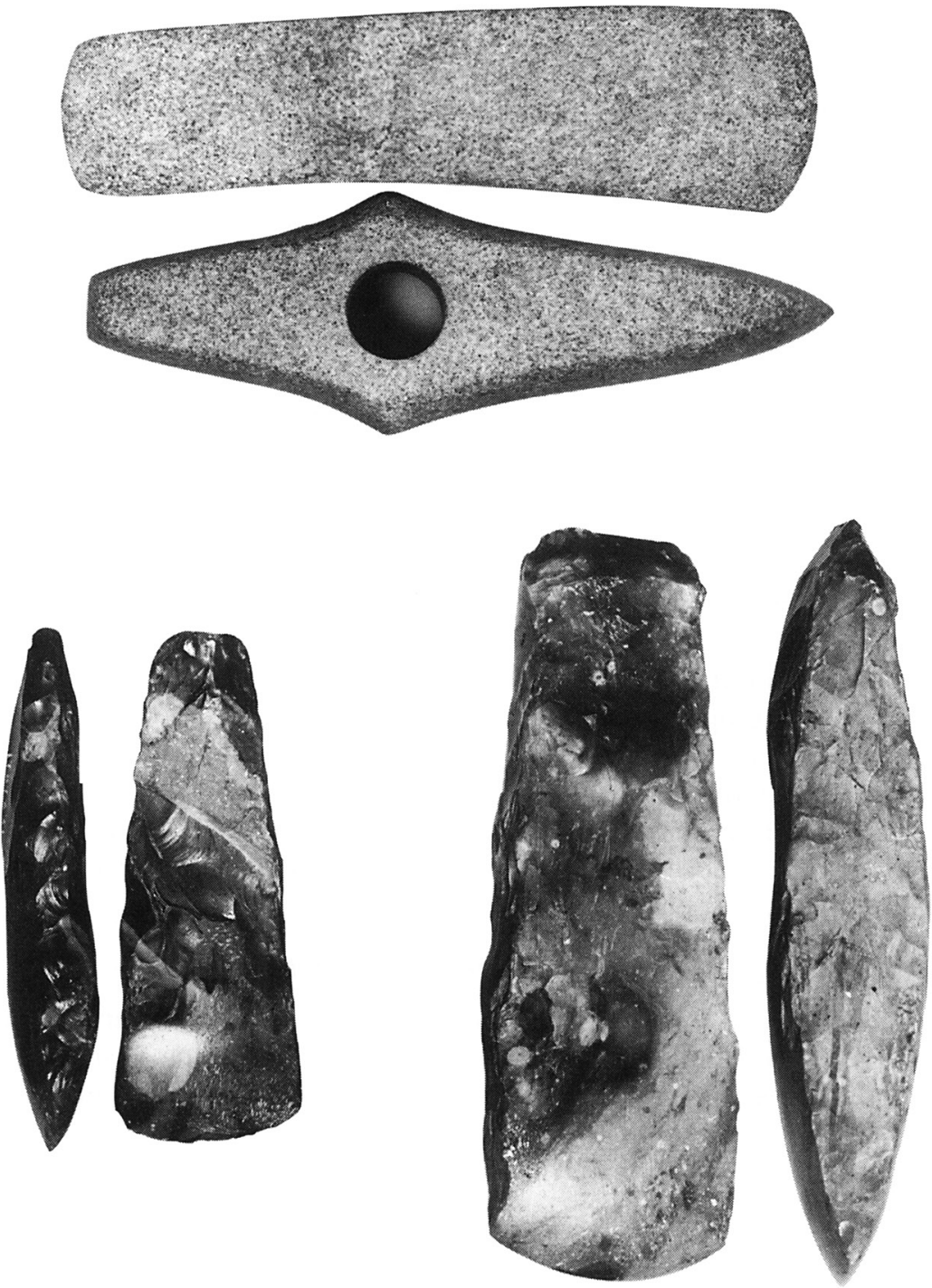

Fig. 14. Gravgodset fra grav 2: Stridsøksen - længde $16,4 \mathrm{~cm}$, og de to flintøkser. En tyknakket - længde $16,9 \mathrm{~cm}$, og en tyndbladet $-11,7 \mathrm{~cm}$ lang. 1:2.

The grave goods from grave 2:The battle axe, length $16.4 \mathrm{~cm}$, and the two flint axes, one thick butted (length $16.9 \mathrm{~cm}$ ), the other thin bladed (length $11.7 \mathrm{~cm}$ ). 1:2. 
Grav 4 - den tredje stenaldergrav - lå midt imellem de to ringgrøftgrave og må være anlagt senere end disse (fig. 15). Da man har kastet høj over denne grav er "tvillingehøjene" blevet til én høj.

Graven var en rektangulær nedgravning med en nærmest flad bund og lodrette sider. Nedgravningen var omtrent øst-vest orienteret, $50 \mathrm{~cm}$ dyb og målte $140 \times 300 \mathrm{~cm}$. Dette anlæg var i modsætning til de foregående helt uden sten.

På bunden fandtes et tyndt lag trækul, hvori strukturerne af tværliggende planker kunne anes (fig. 15). I begge gavlender var der tydelige spor efter trækonstruktioner i form af forkullet træ. Arten af disse var vanskelig at afgøre, men der har måske været tale om tværliggende, kantstillede planker. Ved østgavlen så trækonstruktionen ud til at være væltet lidt ind. Langs siderne fandtes rektangulære aftryk af lodretstående planker. Flere steder langs sydsiden kunne der inden for disse aftryk anes endnu en afgrænsning - formentlig selve kisten. Kistesporene fremtrådte imidlertid kun som et tyndt, brunt, fedtet lag under trækulslaget (plankesporene) og var vanskelige at erkende.

I gravens nordvestlige hjørne fandtes spor af en let forbrændt træpæl og i sydvesthjørnet en planke ligeledes med brandspor; begge har stået lodret.

Der har således været tale om en trækammerkonstruktion med plankebyggede langvægge og bulbyggede gavle omkring en kiste, hvis konstruktion er uvis, men som antagelig har været en plankekiste. Herpå tyder gravens flade bund. Gravanlæggets eneste gravgods - en stridsøkse af Globs type H (12) fandtes ved sydsidens vestlige del (fig. 16).

Omkring grav 4 fandtes enkelte stolpehuller. Disse var dog ret usymmetrisk placeret i forhold til graven, og de var ret forskellige af størrelse og dybde. Det var ikke muligt, at påvise en sammenhæng mellem disse stolpehuller og gravanlægget.

Graven kan ud fra stridsøksens form dateres til enkeltgravskulturens mellemste periode - bundgravstid.

Enkeltgrave med trækammer er ikke ukendte herhjemme, og der er inden for de senere år undersøgt flere af disse anlæg. De viser stor variation i deres indretning spændende fra de nordjyske gravkamre med indgangsåbning (13) til gravkamre uden indgang (14). Alle tre omtalte stenaldergrave i højen Bakkegården - sb. nr. 3 er efter gravgodset at dømme mandsgrave.

\section{Ringgrøftgravene og lignende anlagskomplekser}

Der findes næppe et tidsafsnit i forhistorien med så stor variationsbredde i gravskikken som enkeltgravskulturens periode. Af denne mangfoldighed er gravformen med ringgrøft en af de mere interessante. Anlægstypen kan vel ikke længere siges at være en sjældenhed i Danmark. Siden P.V. Glob i 1944 opregnede ialt 11 grave af typen (15) er der udgravet en del flere hovedsagelig inden for det såkaldte centrale, jyske enkeltgravsområde (16). Et fund af ringgrøftgrave fra Sarup på Fyn viser dog, at typen i Danmark ikke har været ukendt uden for Jylland (17).

Trods tilvæksten af fund er det dog vanskeligt at finde noget, som helt modsvarer fundene fra Rødding f. eks med hensyn til de mange sten. Det fund der viser størst overensstemmelse både med hensyn til opbygningen af anlægget og anvendelsen af sten i både ringgrøft og grav er et enkeltgravsanlæg ved Veldbæk 


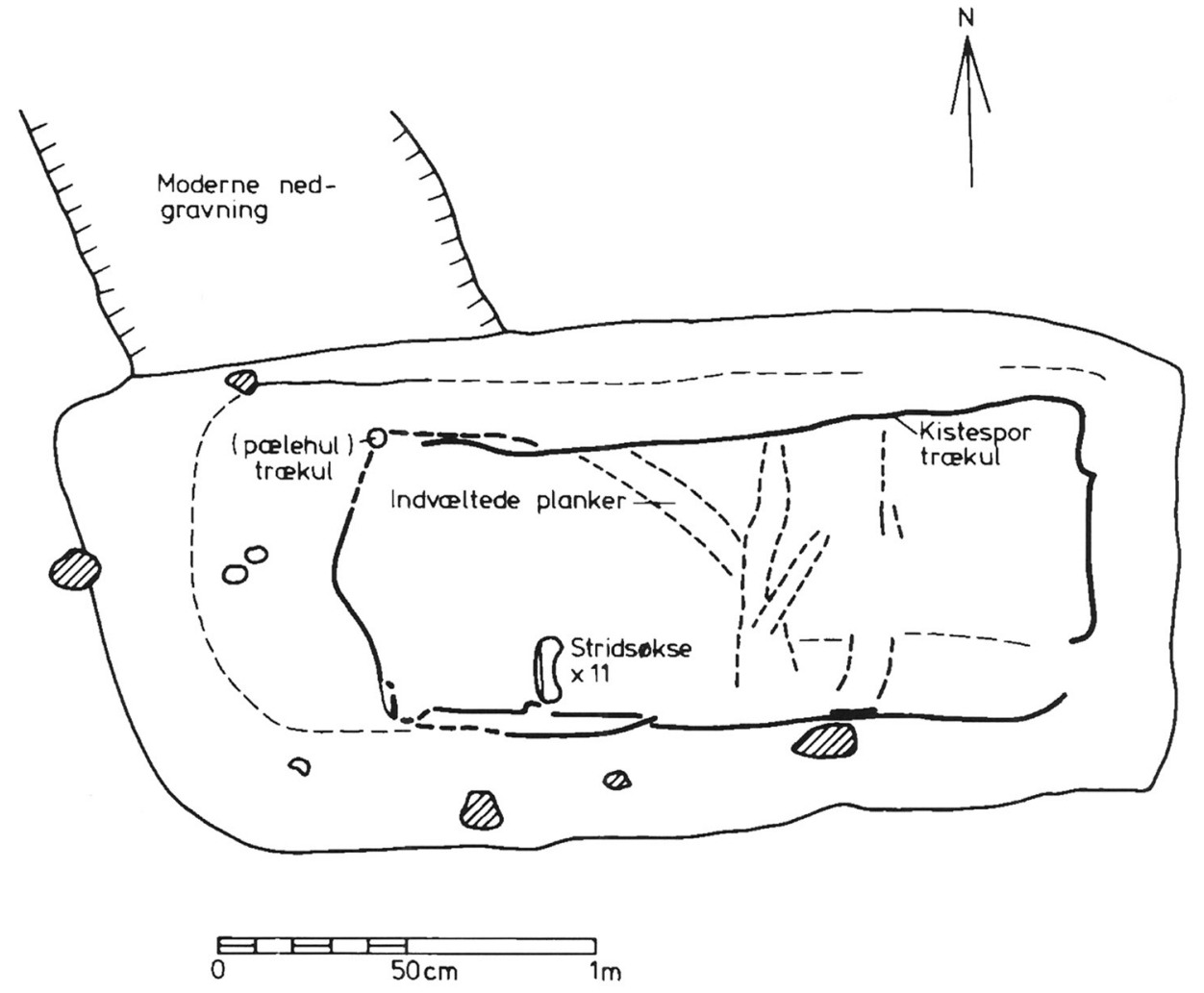

Fig. 15. Grav 4 med stridsøksen og spor af trækammeret frilagt.

Grave 4 with battle axe and traces of wooden chamber exposed.

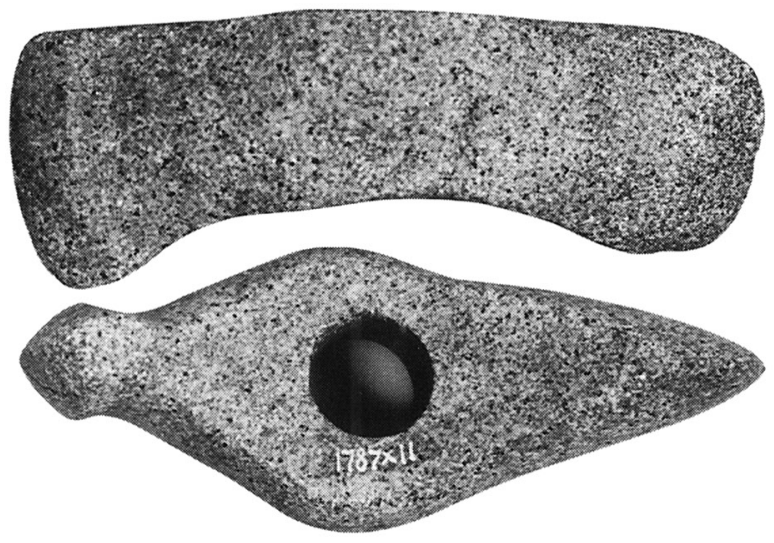

Fig. 16. Stridsøksen fra grav 4 - længde $14,8 \mathrm{~cm} .1: 2$.

The battle axe from grave 4, length $14.8 \mathrm{~cm} .1: 2$. 


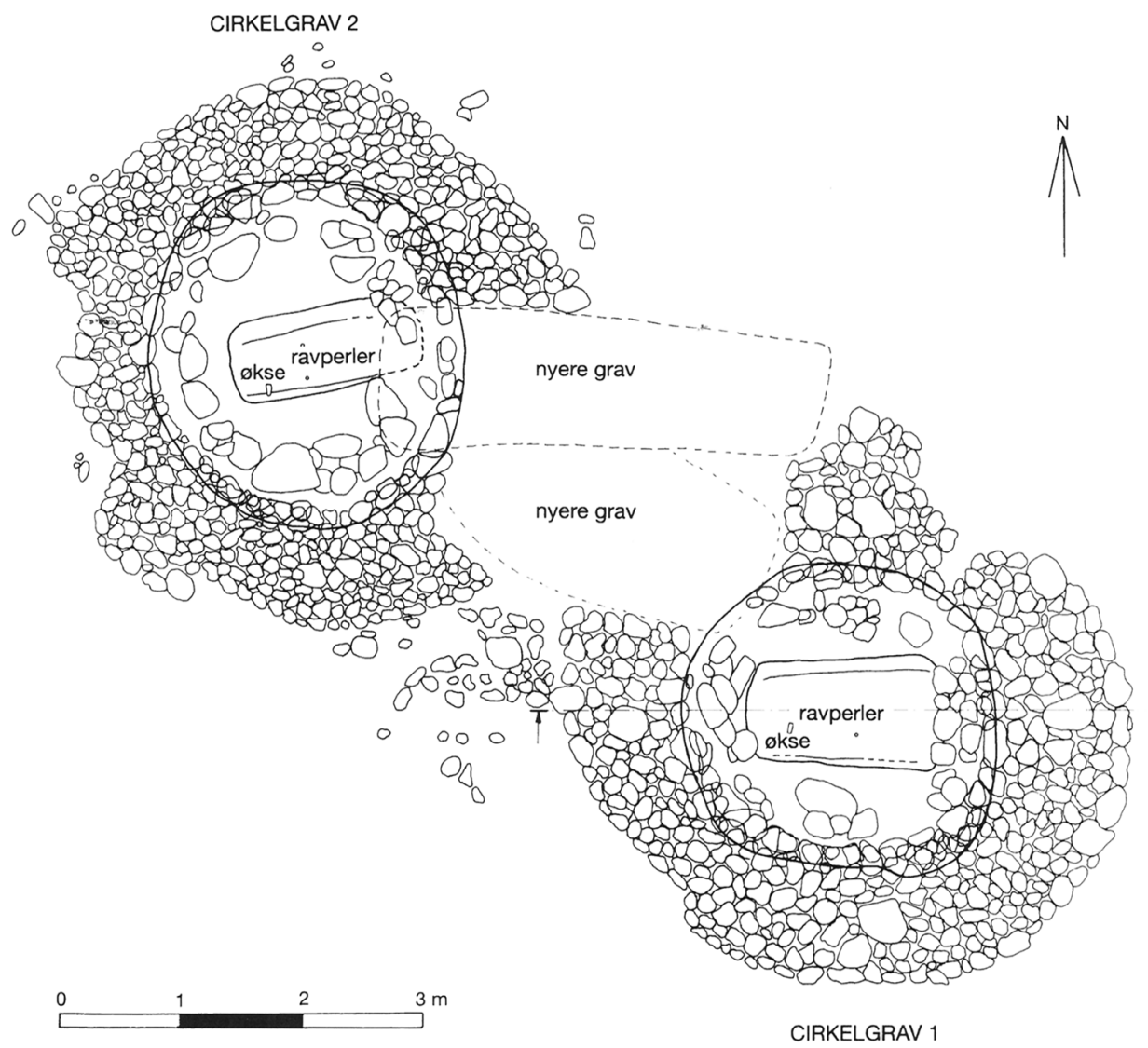

Fig. 17. Neumanns oversigtstegning af anlæggene fra Skærbæk Mølle.

Neumann's survey plan of the features from Skærbæk Mølle.

i nærheden af Esbjerg (18). Her er ringgrøften dog noget større og bundbrolægningen anderledes.

En anden vigtig parallel er Skærbæk Mølle ca. 3,5 km nordvest for Rødding (fig. 17). Her udgravede museumsinspektør Hans Neumann i 1948 et lignende anlæg, men istedet for to ringgrøftgrave er der tale om to cirkelgrave (19) - også her med en mellemliggende grav. Cirkelgravenes konstruktion er lidt anderledes end ringgrøftgravenes, idet både ringgrøft og grav her er anlagt i en stor cirkelrund nedgravning. Fælles er de mange sten i ringgrøfterne. Det er tydeligvis støttesten til en trækonstruktion.

Tolkningen af de to anlægstyper - ringgrøftgrav og cirkelgrav - er ret forskellig. Cirkelgravene tolkes af Neumann som grave med bikubeformet overbygning, mens ringgrøftgravene tolkes som indhegnede begravelser. For begge anlægstyper må der dog være tale om samme funktion, nemlig en åben, afskærmet grav, hvor den døde for en tid har ligget på "lit de parade." 
De to anlægstyper er blevet til på nogenlunde samme tid, idet også cirkelgravene tilhører undergravstid.

Sammenligner man enkeltgravskulturen med andre tidsafsnit, er det slående, hvor stor variationsbredden er med hensyn til gravenes udformning. Alligevel udviser gravanlæggene fra Bakkegården og Skærbæk Mølle så mange lighedspunkter, at gravritualerne måske kan antages at have været meget ensartede inden for snævre lokale områder.

\section{NOTER}

1) Haderslev Museum J.nr. 1764 og 1787. I undersøgelserne deltog fhv. udgravningsformand Holger Lausen, udgravningsformand Carl Anker Thorsager, stud. mag. Niels Hartmann Hansen, museumsassistent Jørgen Holm, arbejdsmand Knud Larsen, maskinfører Jacob Fries samt langtidsledige Birthe Fisker og Laila Nielsen.

2) P.V. Glob: Studier over den jyske enkeltgravskultur. Aarbøger for Nordisk Oldkyndighed og Historie. 1944 , s. $150 \mathrm{ff}$.

3) P.V. Glob 1944, s. 27 og 60.

4) L. Hvass: Enkeltgravskulturens regionalgrupper i Vejle Amt. I: Stridsøksetid i Sydskandinavien 1986, s. 125 - fig. 10.

5) Sb. nr. 3, Rødding sogn.

6) A.B. Sørensen: Bakkegården - grave fra stenalder og jernalder. Lægæst 1985 og P. Ethelberg: Hjemsted 2 - tre gravpladser fra 3. \& 4. årh. e. Kr. 1990, s. 34 ff.

7) Stenene kan være ildskørnede, men der var dog ingen andre tegn på afbrænding i graven. Der er i mange tilfælde rapporteret om ildskørnede eller smuldrende sten i enkeltgrave f.eks. S.E Albrethsen og J. StreetJensen: En højgruppe i Vojens. Aarbøger 1964, s. 21. M. Lauenborg: Kjersing II. Mark og Montre 1980, s. 13.

8) P.V. Glob 1944, s. 22.

9) Fra Horsens-egnen kendes en ringgrøftgrav med en stolpekonstrueret overbygning over graven. O. Madsen: Gantrup. En enkeltgravshøj med ringgrøft og grav med dødehus. Kuml 1988-89 s. 82 ff.

10) J.N. Lanting og J.D. van der Waals: Beaker Culture relations in the lower Rhine Basin. Glockenbecher Symposion 1974 s. 43.

11) Glob 1944, s. 58.

12) Glob 1944, s. 38 og 60-61.

13) Glob 1944 s. 194, M. Hansen: En enkeltgravshøj fra Kjeldgården, Aars. Fra Himmerland og Kjær Herred. 1980, s. 91-100. E. Jørgensen: Brydningstid. Skalk 1985 nr. 2, s. 3-8. O. Schmidt: En stenalders højtomt ved Dalbyneder. Arkæologiske Fund. Kulturhistorisk Museum, Randers 1986, s. 43-45, O. Schmidt \& R. Fiedel: Arkæologiske udgravninger i Danmark 1988 nr. 261, Demstrupvej I, P. Birkedahl: Arkæologiske udgravninger i Danmark 1988 nr. 186, Ø. Hornum.

14) L. \& S. Hvass: Et gravkammer fra enkeltgravskulturen. Kuml 1988-89, s. $57 \mathrm{ff}$.

15) Glob 1944, s. 170.

16) C.J. Becker: Stenaldergrav fra Gabøl. Kuml 1953 , s. 155 ff. H.H. Andersen: Sløjfede enkeltgravshøje ved Stejlgård. Kuml 1961, s. 21 ff. H.J. Madsen: To dobbeltgrave fra jysk enkeltgravskultur. Kuml 1970, s. 249 ff. E. Jørgensen: Et bidrag til diskussionen om tidspunktet for enkeltgravskulturens indvandring. Haderslev Amts Museum 1972. H.C. Vorting: Et usædvanligt enkeltgravsanlæg ved Veldbæk. Mark og Montre 1973. M. Lauenborg 1980 a. a., s. 11. H. Rostholm: Oldtiden på Herning-egnen 1982, s. 43 ff.

17) N.H. Andersen: To grave fra tidlig enkeltgravskultur i Sarup. Fynske Minder 1978, s. 7 ff.

18) Vorting 1973, s. 5 ff.

19) H. Neumann: Udgravninger. Haderslev Amts Museum 1948, s. 5 ff. og Trækonstruktioner over grave fra enkeltgravskulturen. Haderslev Amts Museum1963, s. 20 ff. 


\section{Single Graves near Rødding}

In 1985 Haderslev Museum excavated two ploughed down barrows on elevated land north of Rødding in south Jutland.

In the western barrow, sb. 6 , graves 10 and 11 came to view immediately below the ploughsoil. They lay alongside one another in the middle of the barrow. Both were constructed alike, being rounded-rectangular pits with a flat stone-laid floor surrounded by what remained of a framing of stones. It was apparent from the sections that on the floor of each there had originally been a plank coffin. The structure and grave goods (two amber discs in one, a flint knife and a battleaxe of Globs type 1)5 in the other) date both graves to the early period of the Single Grave Culture - the Bottom Grave Period.

3-400 $\mathrm{m}$ to the east lay another barrow, sb. 3. Despite the strongly ploughed down condition of the site, the excavation gave surprisingly good results. There were three burials from the Single Grave Culture, 8-9 urn burials, mainly from the Pre-Roman and Early Roman Iron Age, and three inhumation graves from the Later Roman Iron Age. Only the Neolithic graves will be described here, graves 1,2 and 4.

Graves 1 and 2 were found to be ring-ditch burials laid out on the same principles: a rounded-rectangular grave pit with flat, stonelaid floor surrounded by a marked stone framing. There had originally been a planken coffin in each of them. Around each had been constructed a ring-ditch with packing stones for the posts that originally enfenced them. Each of the graves contained two flint axes - a thin bladed and a thick butted. In grave 2 there was also a battleaxe of Glob's type B1. Both the form of the graves and their furnishings date them to the Bottom Grave Period.

Grave 4 lay midway between the two ringditch graves. It differed from the other graves in being constructed without using any stones. In the grave had once stood a wooden chamber, in which the coffin had been placed. The grave goods, a battleaxe of Glob's type $\mathrm{H}$, dates the grave to the middle part of the Single Grave Culture, the Ground Grave Period, so this grave is younger than the two with ring ditches.

In 1948 a somewhat similar complex from the same period was excavated at Skærbæk Mølle NW of Rødding. It consisted of two "circle-graves" with a grave between them instead of two graves with ring-ditches. Despite the structural differences circle graves and ring-ditch graves must have had the same function, that of an open protected grave, where the deceased lay on a "lit de parade". There are thus indications that burial customs were very uniform within restricted local areas.
Anne Birgitte Sorensen

Haderslev Museum

Oversattelse: David Liversage 